\title{
BASELINE ASSESSMENT OF THE REEF FISH ASSEMBLAGE FROM CAGARRAS ARCHIPELAGO, RIO DE JANEIRO, SOUTHEASTERN BRAZIL
}

\author{
Carlos A. Rangel*, Laís C. T. Chaves \& Cassiano Monteiro-Neto
}

\author{
Universidade Federal Fluminense \\ Laboratório de Biologia do Nécton e Ecologia Pesqueira \\ Departamento de Biologia Marinha \\ Pós Graduação em Biologia Marinha \\ (Outeiro São João Batista, s/nº, Caixa Postal 100.644, 24001-970, Niterói, RJ, Brasil) \\ *Corresponding author: carlos.a.rangel@gmail.com.
}

\begin{abstract}
A bstract
The extensive Brazilian coast comprises diverse reef fish communities. Here, we report a pioneer study on the reef fish community composition of the Cagarras Archipelago. This rocky reef system consists of a small group of coastal islands $5 \mathrm{~km}$ south off Ipanema Beach, Rio de Janeiro city, Brazil. A relatively diverse and disturbed fish community ( 99 species from 39 families) was found in this archipelago. Two different visual census techniques were utilized and a large difference was observed in the number of species compared to other Brazilian reef sites. Trophic structure and biogeographical affinities are discussed. The absence of some reef fish species, mainly top predators, suggests severe environmental impact in this area and exhorts the Brazilian authorities to create a marine protected area. Results obtained in this study will serve to future environmental studies in Cagarras.
\end{abstract}

\section{R ESUMO}

A extensa costa brasileira abriga uma grande diversidade de peixes recifais. Este trabalho é um estudo pioneiro no que diz respeito à composição de espécies de peixes recifais do Arquipélago das Cagarras. Este sistema recifal é formado por um grupo de ilhas costeiras, distantes $5 \mathrm{~km}$ ao sul da Praia de Ipanema no estado do Rio de Janeiro, Brasil. Uma comunidade relativamente diversa e impactada, com 99 espécies pertencentes a 39 famílias de peixes recifais, foi encontrada. A utilização de duas técnicas de censo visual mostrou uma grande diferença nos dados obtidos, quando comparados a outras regiões recifais brasileiras. São discutidos dados da estrutura trófica e a distribuição biogeográfica da ictiofauna da região. A ausência de algumas espécies, principalmente grandes predadores, sugere que a região está sofrendo grande impacto ambiental, e torna urgente a criação de uma área de proteção marinha pelas autoridades Brasileiras. Os resultados obtidos poderão servir como base para futuros estudos ambientais nas Cagarras.

Descriptors: Cagarras Archipelago, Reef fishes, Visual census, Trophic category, Biogeographical affinity, Anthropogenic impacts, Conservation.

Descritores: Arquipélago das Cagarras, Peixes recifais, Censo visual, Estrutura trófica, Distribuição biogeográfica, Impactos antropogênicos, Conservação.

\section{INTRODUCTION}

Reef areas represent the most diverse marine ecosystems (Paulay, 1997). The greatest diversity of flora and fauna is concentrated in the tropics, following the distribution of hermatypic corals within the $20^{\circ} \mathrm{C}$ isotherm (Spalding et al., 2001). Tropical fishes follow nearly the same pattern, but due to their plasticity and relative long pelagic larval duration (PLD), many species move into subtropical zones extending their distribution and occupying reef habitats not fully exploited by their temperate counterparts (Choat \& Bellwood, 1991). Fishes use reefs mostly as sheltering, feeding, and reproduction (Sale, 1991).
In tropical regions reef fishes are a food source to a large portion of the coastal population (Munro, 1996). Unfortunately, fishing production in reef systems worldwide, suffered drastic declines due to environmental degradation and application of inadequate management techniques (Polunin \& Roberts, 1996; Roberts \& Hawkins, 2000).

The Brazilian shoreline extends approximately over $8000 \mathrm{~km}$, and reefs are an important physiographic feature throughout the coast, occurring at least along a third of this coastline. Coral reefs predominate northwards $\left(0^{\circ} 52^{\prime} \mathrm{N}-19^{\circ} \mathrm{S}\right)$ and rocky reefs southwards $\left(20^{\circ} \mathrm{S}-28^{\circ} \mathrm{S}\right)$ (Floeter et al., 2006). Despite the wide distribution of reef environments throughout the Brazilian coast and inner shelf waters, 
just recently we begun to understand some of fisheries impacts on these ecosystems (Dutra et al., 2005; Floeter et al., 2006; Frédou et al., 2006), and to implement management and conservation actions to protect them.

The Cagarras Archipelago is a small group of coastal islands located about $5 \mathrm{~km}$ south of Ipanema Beach, Rio de Janeiro, southeastern Brazil. This area concentrates a great diversity of fauna and flora and constitutes a unique quasi-tropical environment within the subtropical waters in Brazil (Secchin, 2002; Lodi, 2002). The Archipelago was considered as one of the priority areas for conservation actions (MMA 1999; MMA 2002) and a National Bill is under review for establishing the Cagarras Archipelago Natural Monument conservation unit (BRASIL, 2003). Nevertheless, to date, there is no accurate checklist of marine fishes for this area, despite its importance and proximity to one of the largest urban centers in Brazil (i.e. Rio de Janeiro City).

The fish fauna of Cagarras is under threat by destructive harvesting techniques (trawlers, dynamite fishing, predatory spear fishing), lack of control of recreational visitors, and ornamental fish trade, as well as the indiscriminate collection of marine organisms for consumption (Secchin, 2002; Lodi, 2002). Such impacts endorse the necessity for basic knowledge on the fish communities to support effective measures against environmental degradation and biodiversity protection in the area.

This study provides the first assessment of the reef fish assemblage at the Cagarras Archipelago, characterizing species composition and abundance, trophic structure and biogeographical affinity. It also provides insights on possible anthropogenic impacts within the areas considered in this study.

Material and Methods

Study Area

The Cagarras Archipelago ( $\left.23^{\circ} 02^{\prime} \mathrm{S}, 43^{\circ} 12^{\prime} \mathrm{W}\right)$ is situated off the coast of Rio de Janeiro, southeast Brazil (Fig. 1). The archipelago comprises three main islands (Cagarra, de Palmas and Comprida), three lesser islands, and seven near-surface rocky reefs. Two isolated islands, Redonda and Rasa, have been recently included as part of the Archipelago. The proximity of this insular system to a large urban center facilitates the access of visitors to its natural resources. The area is also directly affected by the Ipanema marine sewage disposal system that discharges a load of approximately $6.5 \mathrm{~m}^{3} / \mathrm{s}$ (CEDAE - Companhia Estadual de Águas e Esgotos, Rio de Janeiro, pers. comm.) at less than $2 \mathrm{~km}$ from the islands (Fig. 1). In addition, the area suffers great influence of the eutrophic waters of Guanabara Bay, the second largest bay environment in Brazil (Valentin et al., 1999) (Fig. 1). The bay is the final receptor of domestic and industrial wastes from 16 municipalities and a total population of approximately 11 million people. Nearly 55 rivers and creeks drain into the bay (Portal Baía de Guanabara, 1997).

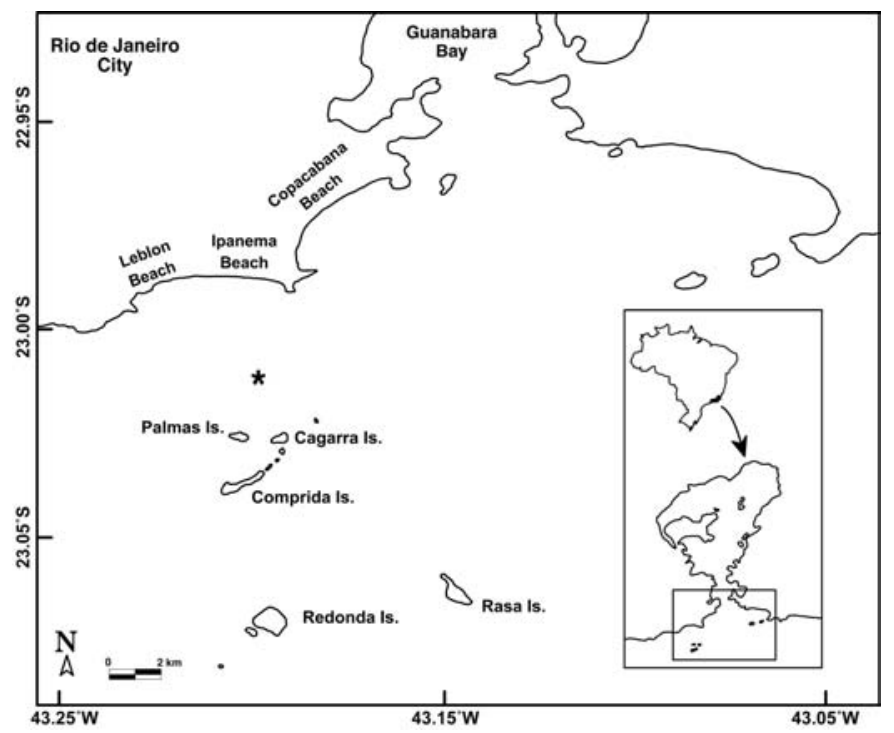

Fig. 1. Map of study area showing the geographical location of Guanabara Bay on the Brazilian coast (inset), the five islands of the Cagarras Archipelago, and the sewage disposal site of the Ipanema Sewage Disposal System $(*)$. 


\section{Community Data}

The study was conducted between July and December 2005, using two different small vessels adapted for diving and tourism operations. The Archipelago was visited from one to three times a month, a total of ten trips during the study period. Diving was conducted in conditions of average visibility of $10.1 \mathrm{~m}$, surface water temperatures of $22^{\circ} \mathrm{C}$, and maximum depths ranging between 10 to 28 $\mathrm{m}$.

The occurrence and abundance of reef fishes were obtained through two different non-destructive underwater visual census (UVC) methods, both using SCUBA diving, conducted by two trained research divers experienced in underwater fish identification (C.A.R. and L.C.T.C.).

\section{a) Rover-diver counts}

Rover-diver counts were used to build a checklist of fishes and obtain qualitative data for the Cagarras reef fish community. The rover-diver technique consists of recording the species observed during the whole diving interval. Research diver swims randomly, from the surface to the maximum diving depth at each site, recording the maximum number of species encountered. No abundance or size data is collected (Baron et al., 2004). These qualitative data were recorded during sporadic dives at randomly selected sites located on three islands of the Archipelago (Comprida, Redonda and Rasa, Fig. 1). The species visualized were recorded on PVC slates at the moment of observation.

\section{b) Transect-counts}

Transect counts were conducted to obtain quantitative community data. Strip-transect is one of the most popular non-destructive methods for multispecies studies. The diver follows a straight line over the substrate, measuring the transect distance with a fiberglass measuring tape, and counting fishes within $2 \mathrm{~m}$ ( $1 \mathrm{~m}$ to each side of the observer). Transect sites were chosen haphazardly on the leeward side of Comprida Is. In the present study, transects were performed from the bottom interface (maximum depth at each site) to the surface, recording species across different depths. Due to different depth ranges, the area surveyed varied between transects, but each transect covered approximately $58.5 \mathrm{~m}^{2}$ on average. Abundance data for each species were recorded on PVC slates and later converted into density (fish/10 $\mathrm{m}^{2}$ ) to minimize differences between uneven transects.

All counts were conducted during daylight ( 0900 to $1500 \mathrm{~h}$ ). Transect counts were not conducted whenever horizontal visibility was less than $3 \mathrm{~m}$. However, rover diver counts were conducted in all occasions.

Specialized literature was utilized to obtain trophic category data (Ferreira et al., 2004; Floeter et al., 2004) and distribution of each species (Joyeux et al., 2001; Froese \& Pauly, 2006; Ferreira et al., in press).

In our study, however, we used a simplified trophic structure model, adapted from Ferreira et al. (2004), for the Cagarras Archipelago reef fish community. Fishes were grouped into five trophic categories: Herbivores (HB) - fishes that feed mostly on algae and include different behaviors such as territorial, browsing, and roving fishes; Invertebrates feeders (IN) - feed mostly on sessile and mobile invertebrates; Carnivores (CR) - feed mostly on fishes, but also include invertebrates on their diet; Planktivores (PK) - includes day and night planktivores feeding on micro- and macrozooplankton, and Omnivores (OM) - feed on algae, detritus and small invertebrates.

\section{RESULtS \\ Species Richness}

A total of 99 species of reef fishes belonging to 39 families were recorded. A checklist of fishes from Cagarras Archipelago is presented in Table 1. The most speciose families were Serranidae (11 spp.), Labridae (7 spp.), Haemulidae and Pomacentridae (both with 6 spp.), Pomacanthidae and Labrisomidae (both with 5 spp.) and Blenniidae (4 spp.).

Table 1 also indicates the most harvested reef fishes by the aquarium trade in Brazil observed in Cagarras Archipelago.

\section{Trophic Structure}

Among the species sampled, almost half of the fishes observed (44\%) were invertebrate feeders (In), including 17 families, with Labridae (6 spp.) and Haemulidae (5 spp.) with greatest species richness. Carnivorous $(\mathrm{Ca})$ represented $24 \%$ and included 12 families, with Serranidae (7 spp.) and Carangidae (3 spp.) as the richest families. Omnivores $(\mathrm{Om})$ matched $14 \%$, with 9 families. Most representative families were Blenniidae and Monacanthidae, both with 3 species each. Herbivores (He) accounted for $12 \%$ of the species and included Scaridae (4 spp.), Acanthuridae (3 spp.) and Pomacentridae (3 spp.). Planktivores $(\mathrm{Pk})$ was the smallest group and represented $6 \%$ of the total number of species including 5 families, with Pomacentridae the most representative, mostly due to the occurrence of the genus Chromis, with 2 spp (Fig. 2). 
Table 1. Checklist of reef fishes from Cagarras Archipelago. Data of trophic category and biogeographical affinity are given. Families are arranged according to Nelson (1994) and Carvalho-Filho (1999). Ca, Carnivores; Pk, Planktivores; In, invertivores; Om, omnivores; Hb, herbivores. $\boldsymbol{\Psi}$ - Reef fishes most harvested for the aquarium trade in Brazil (35 spp.) $\Rightarrow 35.35 \%$ of reef fishes from Cagarras Archipelago. $\Psi+$ - Top reef fishes most harvested - High Pressure - (11 spp.) $=>11.11 \%$ of reef fishes from Cagarras Archipelago (Monteiro-Neto et al., 2003; Gasparini et al., 2005).

\begin{tabular}{|c|c|c|c|}
\hline Family & Species & Trophic category & Biogeographical Affinity \\
\hline \multirow[t]{2}{*}{ Muraenidae } & Gymnothorax cf. moringa (Cuvier, 1829) & $\mathrm{Ca}$ & Western Atlantic \\
\hline & Gymnothorax funebris Ranzani, 1840 & $\mathrm{Ca}$ & Circumtropical \\
\hline Ophichtidae & Myrichthys breviceps (Richardson, 1848) $\Psi$ & In & Western Atlantic \\
\hline \multirow[t]{2}{*}{ Synodontidae } & Synodus synodus (Linnaeus, 1758) & $\mathrm{Ca}$ & Western Atlantic \\
\hline & Synodus intermedius (Spix \& Agassiz, 1829) & $\mathrm{Ca}$ & Western Atlantic \\
\hline Ogcocephalidae & Ogcocephalus vespertilio (Linnaeus, 1758) $\Psi$ & In & Western Atlantic \\
\hline \multirow[t]{2}{*}{ Holocentridae } & Holocentrus adscensionis (Osbeck, 1765) & In & Western Atlantic \\
\hline & Myripristis jacobus Cuvier, 1829 & In & Western Atlantic \\
\hline Fistularidae & Fistularia tabacaria Linnaeus, 1758 & $\mathrm{Ca}$ & Western Atlantic \\
\hline Syngnathidae & Hippocampus aff. reidi Ginsburg, $1933 \Psi$ & $\mathrm{Om}$ & Southwestern Atlantic (Brazilian Province) \\
\hline Belonidae & Strongylura sp. van Hasselt , 1824 & $\mathrm{Ca}$ & Western Atlantic \\
\hline Dactylopteridae & Dactylopterus volitans (Linnaeus, 1758) & In & Amphi-Atlantic and Mediterranean \\
\hline \multirow[t]{3}{*}{ Scorpaenidae } & Scorpaena plumieri Bloch, 1789 & $\mathrm{Ca}$ & Circumtropical \\
\hline & Scorpaena isthmensis Meek \& Hildebrand, 1928 & $\mathrm{Ca}$ & Western Atlantic \\
\hline & Scorpaena brasiliensis Cuvier, 1829 & $\mathrm{Ca}$ & Western Atlantic \\
\hline \multirow[t]{8}{*}{ Serranidae } & Acanthistius brasilianus (Cuvier 1828) & In & Southwestern Atlantic \\
\hline & Dules auriga (Cuvier, 1829) & In & Western Atlantic \\
\hline & Epinephelus marginatus (Lowe, 1834) & $\mathrm{Ca}$ & Western Atlantic \\
\hline & Epinephelus morio (Valencienes, 1828) & $\mathrm{Ca}$ & Western Atlantic \\
\hline & Epinephelus niveatus (Valencienes, 1828) & $\mathrm{Ca}$ & Western Atlantic \\
\hline & Mycteroperca acutirostris (Valencienes, 1828) & $\mathrm{Ca}$ & Western Atlantic \\
\hline & Mycteroperca interstitialis (Poey, 1860) & $\mathrm{Ca}$ & Western Atlantic \\
\hline & Serranus baldwini (Evermann \& Marsh, 1900) & In & Western Atlantic \\
\hline \multirow[t]{3}{*}{ Serranidae } & Paranthias furcifer (Valencienes, 1828) & $\mathrm{Pk}$ & Western Atlantic \\
\hline & Rypticus bistrispinus (Mitchill, 1818) & $\mathrm{Ca}$ & Western Atlantic \\
\hline & Rypticus saponaceus (Bloch \& Schneider, 1801) & $\mathrm{Ca}$ & Amphi-Atlantic \\
\hline Priacanthidae & Heteropriacanthus cruentatus (Lacepède, 1801) & $\mathrm{Ca}$ & Circumtropical \\
\hline \multirow[t]{4}{*}{ Carangidae } & Caranx crysos (Mitchill, 1815) & $\mathrm{Ca}$ & Western Atlantic \\
\hline & Caranx ruber (Bloch, 1793) & $\mathrm{Ca}$ & Western Atlantic \\
\hline & Pseudocaranx dentex (Bloch \& Schneider, 1801) & $\mathrm{Pk}$ & Western Atlantic \\
\hline & Seriola rivoliana Valenciennes, 1833 & $\mathrm{Ca}$ & Western Atlantic \\
\hline Lutjanidae & Ocyurus chrysurus (Bloch, 1791) & $\mathrm{Ca}$ & Western Atlantic \\
\hline \multirow[t]{6}{*}{ Haemulidae } & Anisotremus virginicus (Linnaeus, 1758) $\Psi$ & $\mathrm{Ca}$ & Western Atlantic \\
\hline & Anisotremus surinamensis (Bloch, 1791) & In & Western Atlantic \\
\hline & Haemulon aurolineatum Cuvier, 1829 & In & Western Atlantic \\
\hline & Haemulon steindachneri (Jordan \& Gilbert, 1882) & In & Circumtropical \\
\hline & Haemulon plumieri (Lacepède,1802) & In & Western Atlantic \\
\hline & Orthopristis ruber (Cuvier, 1830) & In & Western Atlantic \\
\hline
\end{tabular}


Table 1. Continued

\begin{tabular}{|c|c|c|c|}
\hline Family & Species & Trophic category & Biogeographical Affinity \\
\hline \multirow[t]{2}{*}{ Sparidae } & Calamus pennatula Guichenot, 1868 & Om & Western Atlantic \\
\hline & Diplodus argenteus (Valenciennes, 1830) & Om & Western Atlantic \\
\hline \multirow[t]{2}{*}{ Sciaenidae } & Odontoscion dentex (Cuvier, 1830) & In & Western Atlantic \\
\hline & Pareques acuminatus (Bloch \& Schneider, 1801) $\Psi$ & In & Western Atlantic \\
\hline Mullidae & Pseudupeneus maculatus (Bloch, 1793) & In & Western Atlantic \\
\hline Pempheridae & Pempheris schomburgkii Müller \& Troschel, 1848 & $\mathrm{Pk}$ & Western Atlantic \\
\hline Kyphosidae & Kyphosus sectatrix (Linnaeus, 1758) & $\mathrm{Hb}$ & Western Atlantic \\
\hline Ephippidae & Chaetodipterus faber (Broussonet, 1782) & Om & Western Atlantic \\
\hline \multirow[t]{3}{*}{ Chaetodontidae } & Chaetodon sedentarius Poey, $1860 \Psi$ & In & Western Atlantic \\
\hline & Chaetodon striatus Linnaeus, $1758 \Psi$ & In & Western Atlantic \\
\hline & Prognathodes guyanensis (Durand, 1960) $\Psi$ & In & Western Atlantic \\
\hline \multirow[t]{5}{*}{ Pomacanthidae } & Pomacanthus paru (Bloch, 1787) $\Psi+_{+}$ & $\mathrm{Om}$ & Western Atlantic \\
\hline & Pomacanthus arcuatus (Linnaeus, 1758) $\Psi+$ & In & Western Atlantic \\
\hline & Holacanthus ciliaris (Linnaeus, 1758) $\Psi_{+}$ & In & Western Atlantic \\
\hline & Holacanthus tricolor (Bloch, 1795) $\Psi+_{+}$ & In & Western Atlantic \\
\hline & Centropyge aurantonotus Burgess, $1974 \Psi+$ & In & W. Atlantic (South of Caribbean to Brazil) \\
\hline \multirow[t]{6}{*}{ Pomacentridae } & Abudefduf saxatilis (Linnaeus, 1758) $\Psi$ & $\mathrm{Om}$ & Western Atlantic \\
\hline & Chromis jubauna Moura,1995 $\Psi_{+}$ & $\mathrm{Pk}$ & Southwestern Atlantic (Brazilian Province) \\
\hline & Chromis multilineata (Guichenot, 1853) $\Psi$ & $\mathrm{Pk}$ & Western Atlantic \\
\hline & Stegastes fuscus (Cuvier, 1830) $\Psi$ & $\mathrm{Hb}$ & Southwestern Atlantic (Brazilian Province) \\
\hline & Stegastes pictus (Castelnau, 1855) $\Psi$ & $\mathrm{Hb}$ & Western Atlantic \\
\hline & $\begin{array}{l}\text { Stegastes variabilis (Castelnau, 1855) } \Psi+ \\
\text { Clepticus brasiliensis Heiser, Moura \& Robertson, }\end{array}$ & $\mathrm{Hb}$ & Western Atlantic \\
\hline \multirow[t]{7}{*}{ Labridae } & 2001 & $\mathrm{Pk}$ & Southwestern Atlantic (Brazilian Province) \\
\hline & Bodianus pulchellus (Poey, 1860) $\Psi+$ & In & Western Atlantic \\
\hline & Bodianus rufus (Linnaeus, 1758) $\Psi_{+}$ & In & Western Atlantic \\
\hline & Halichoeres poeyi (Steindachner, 1867) & In & Western Atlantic \\
\hline & Halichoeres brasiliensis (Bloch,1791) $\Psi$ & In & Western Atlantic \\
\hline & Halichoeres bathyphilus (Beebe \& Tee-Van, 1932) & In & Western Atlantic \\
\hline & Halichoeres dimidiatus (Agassiz, 1831) $\Psi+_{+}$ & In & $\begin{array}{l}\text { Southwestern Atlantic (Brazilian Province) } \\
\text { Southwestern Atlantic (occurs in }\end{array}$ \\
\hline Pinguipedidae & Pinguipes brasilianus Cuvier, 1829 & $\mathrm{Ca}$ & Mediterranean*) \\
\hline \multirow[t]{4}{*}{ Scaridae } & Sparisoma axillare (Steindachner, 1878) & $\mathrm{Hb}$ & Southwestern Atlantic (Brazilian Province) \\
\hline & Sparisoma frondosum (Agassiz, 1831) & $\mathrm{Hb}$ & Southwestern Atlantic (Brazilian Province) \\
\hline & $\begin{array}{l}\text { Sparisoma tuiupiranga Gasparini, Joyeux \& Floeter, } \\
2003 \Psi\end{array}$ & $\mathrm{Hb}$ & Southwestern Atlantic (Brazilian Province) \\
\hline & $\begin{array}{l}\text { Scarus zelindae Moura, Figueiredo \& Sazima, } 2001 \\
\Psi\end{array}$ & $\mathrm{Hb}$ & Southwestern Atlantic (Brazilian Province) \\
\hline \multirow[t]{5}{*}{ Labrisomidae } & Labrisomus nuchipinnis (Quoy \& Gaimard, 1824) & In & Amphi-Atlantic \\
\hline & Labrisomus cricota Sazima, Gasparini \& Moura, 2002 & In & Southwestern Atlantic (Brazilian Province) \\
\hline & Labrisomus kalisherae (Jordan, 1904) & In & Western Atlantic \\
\hline & Malacoctenus delalandii (Valenciennes, 1836) & In & Western Atlantic \\
\hline & Malacoctenus aff. triangulatus in description & In & Southwestern Atlantic (Brazilian Province) \\
\hline Chaenopsidae & Emblemariopsis signifera (Ginsburg, 1942) & In & Western Atlantic \\
\hline Blenniidae & Parablennius marmoreus (Poey, 1876) $\Psi$ & $\mathrm{Om}$ & Western Atlantic \\
\hline
\end{tabular}


Table 1. Continued.

\begin{tabular}{|c|c|c|c|}
\hline Family & Species & Trophic category & Biogeographical Affinity \\
\hline & Scartella cristata (Linnaeus, 1758) $\Psi$ & $\mathrm{Hb}$ & Amphi-Atlantic and Mediterranean \\
\hline & Hypleurochilus fissicornis (Quoy \& Gaimard, 1824) & $\mathrm{Om}$ & Southwestern Atlantic \\
\hline \multirow[t]{2}{*}{ Gobiidae } & Elacatinus figaro Sazima, Moura \& Rosa, 1997 \%+ & In & Southwestern Atlantic (Brazilian Province) \\
\hline & Coryphopterus glaucofrenum Gill, 1863 & In & Western Atlantic \\
\hline \multirow[t]{3}{*}{ Acanthuridae } & Acanthurus bahianus Castelnau, 1855 & $\mathrm{Hb}$ & Western Atlantic \\
\hline & Acanthurus chirurgus (Bloch, 1787) & $\mathrm{Hb}$ & Western Atlantic \\
\hline & Acanthurus coeruleus Bloch e Schneider, $1801 \Psi$ & $\mathrm{Hb}$ & Western Atlantic \\
\hline Bothidae & Bothus ocellatus (Agassiz, 1831) & In & Western Atlantic \\
\hline Balistidae & Balistes vetula Linnaeus, $1758 \Psi$ & Om & Western Atlantic \\
\hline \multirow[t]{3}{*}{ Monacanthidae } & Cantherhines pullus (Ranzani, 1842) $\Psi$ & Om & Western Atlantic \\
\hline & Cantherhines macroceros (Hollard, 1853) $\Psi$ & Om & Western Atlantic \\
\hline & Stephanolepis hispidus (Linnaeus, 1766) & Om & Western Atlantic \\
\hline Ostraciidae & Lactophrys trigonus (Linnaeus, 1758) & $\mathrm{Om}$ & Western Atlantic \\
\hline \multirow[t]{3}{*}{ Tetraodontidae } & Canthigaster figueiredoi Moura \& Castro, $2002 \Psi$ & In & Western Atlantic \\
\hline & Sphoeroides spengleri (Bloch, 1785) & In & Western Atlantic \\
\hline & Sphoeroides testudineus (Linnaeus, 1758) & In & Western Atlantic \\
\hline \multirow[t]{2}{*}{ Diodontidae } & Diodon hystrix Linnaeus, $1758 \Psi$ & In & Western Atlantic \\
\hline & Chilomycterus spinosus (Linnaeus, 1758) $\Psi$ & In & Western Atlantic \\
\hline Myliobatidae & Aetobatus narinari (Euphrasen, 1790) & $\mathrm{Ca}$ & Circumtropical \\
\hline
\end{tabular}

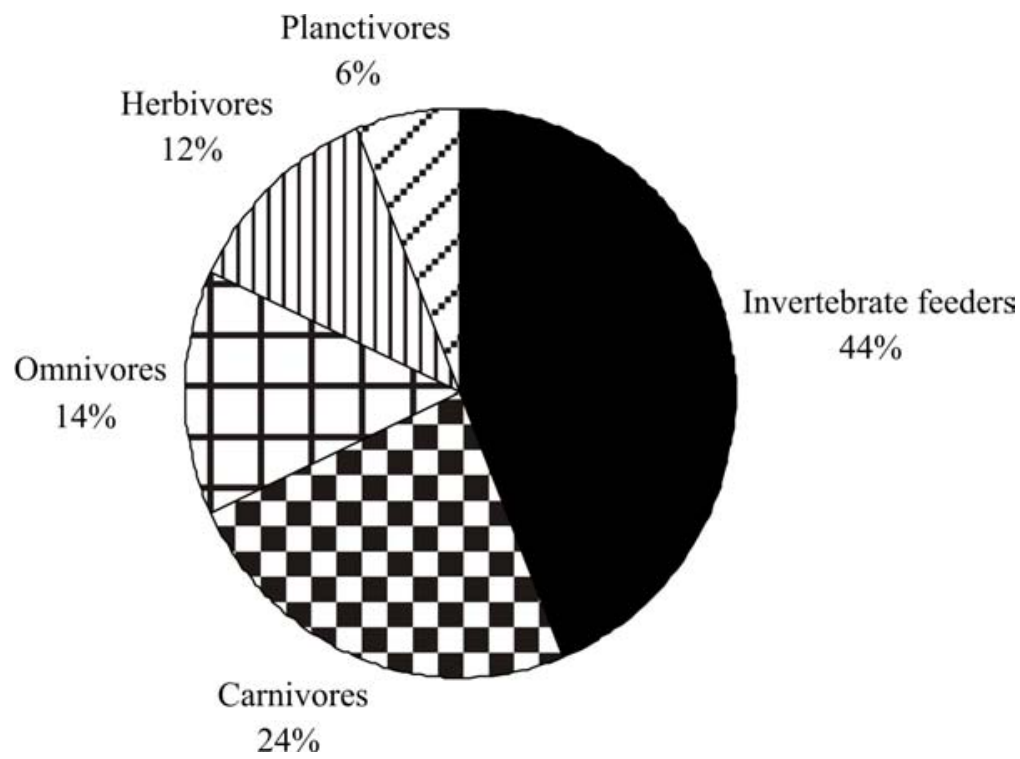

Fig. 2. Trophic categories of reef fish species recorded in Cagarras Archipelago. 
Biogeographical Affinity

The majority of the species $(75 \%)$ is widely distributed in the Southern and Northern Western Atlantic, $15 \%$ are restricted to the southwestern Atlantic (Brazilian Province). Only 5\% of the species have worldwide distribution, $3 \%$ occur on both sides of the Atlantic Ocean, and 2\% occur on both sides of the Atlantic Ocean and the Mediterranean Sea (Fig. 3).

Quantitative Data

Transect counts recorded 1314 fishes in $702 \mathrm{~m}^{2}$. The most representative families were Monacanthidae, Pomacentridae, Sparidae, Haemulidae and Labridae (Fig. 4). Most abundant species were
Stephanolepis hispidus (3.5 fishes $/ 10 \mathrm{~m}^{2}$ ), Diplodus argenteus (3 fishes $\left./ 10 \mathrm{~m}^{2}\right)$, Abudefduf saxatilis $(2.1$ fishes/10 $\left.\mathrm{m}^{2}\right)$, Haemulon aurolineatum (1.3 fishes/10 $\left.\mathrm{m}^{2}\right)$ and Chromis multilineata (1.3 fishes $\left./ 10 \mathrm{~m}^{2}\right)$. Altogether they comprised $60 \%$ of the total fishes recorded (Fig. 5).

Overall, the omnivores were the most numerous $\left(9.3\right.$ fishes $\left./ 10 \mathrm{~m}^{2}\right)$, followed by invertivores (6.3 fishes $\left./ 10 \mathrm{~m}^{2}\right)$. The mobile behavior of the top predators, such as jacks (Carangidae) and snappers (Lutjanidae) and the few records of groupers and basses (Serranidae), kept carnivores as the least abundant guild (Fig. 6). Roving herbivores, such as Acanthuridae and Scaridae, accounted for $90 \%$ of the herbivores leaving only $10 \%$ to territorial ones, such as Stegastes spp.

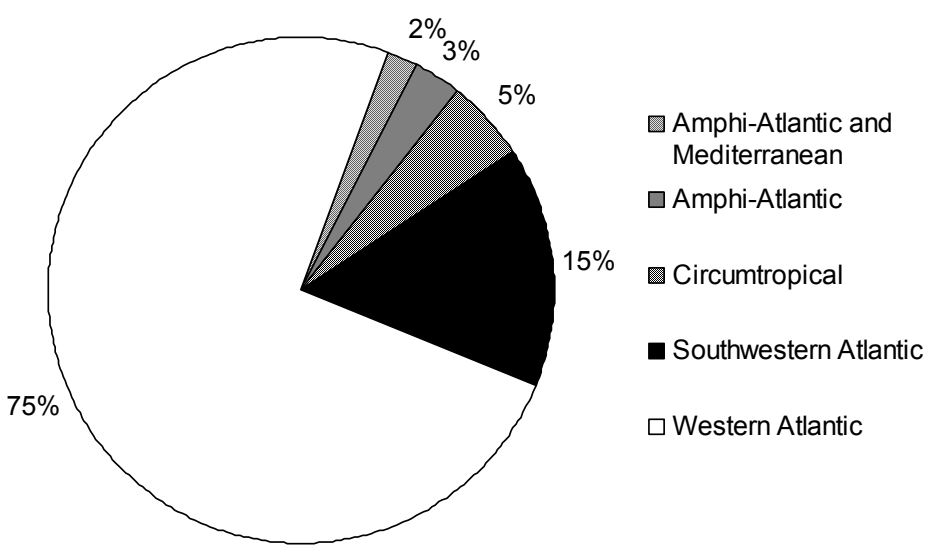

Fig. 3. Biogeographical affinity of reef fish species recorded in the Cagarras Archipelago.

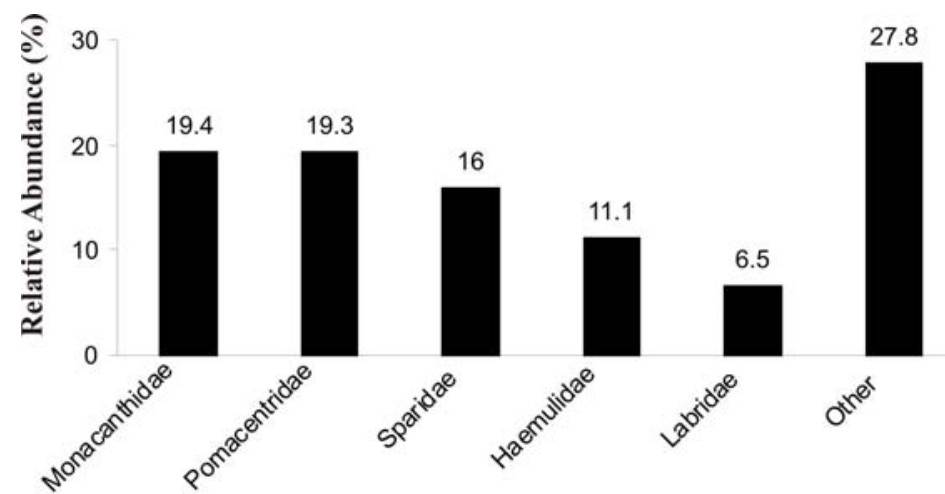

Families

Fig. 4. Most abundant families recorded in quantitative TVC at Comprida Island. 


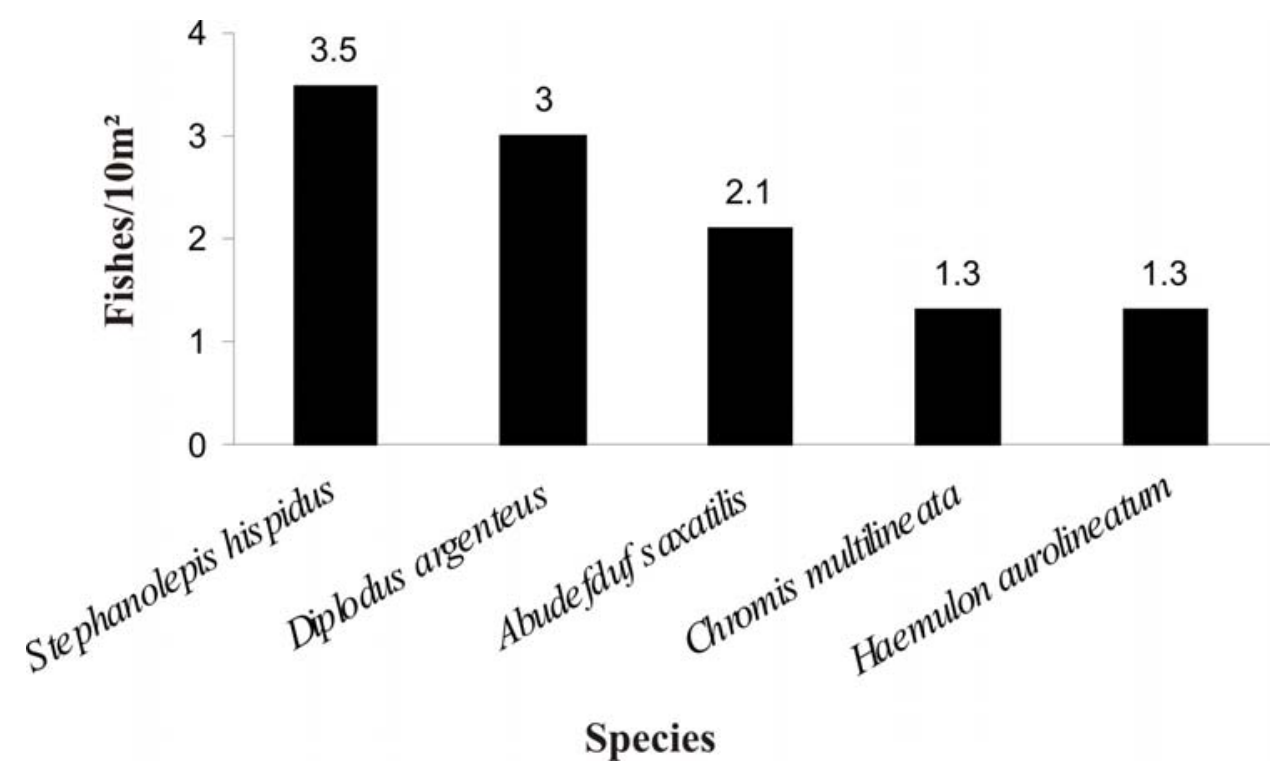

Fig. 5. The most abundant species in Comprida Island $(\mathrm{N}=1314)$.

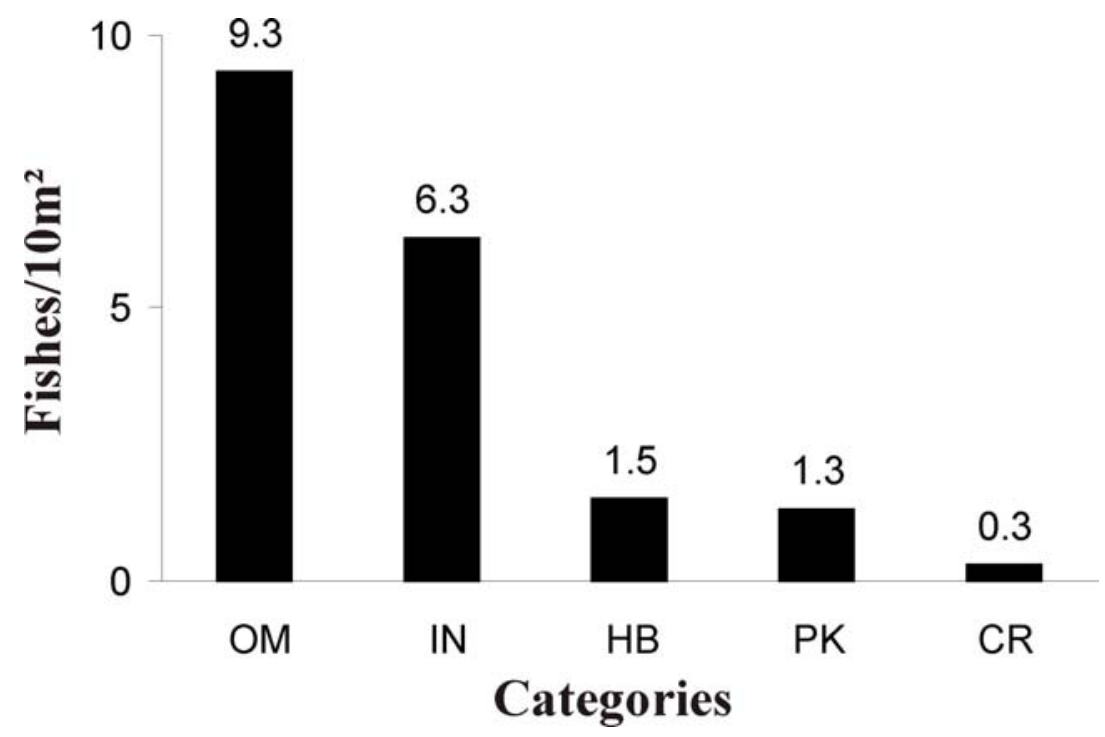

Fig. 6. Numerical abundance (density) of trophic categories in Comprida Island. HB-herbivores; PKplanktivores; OM-omnivores; IN-invertebrate feeders; CR-carnivores. 


\section{DisCUSSION}

Our study presents evidences that the reef fish fauna in the Cagarras Archipelago is relatively diverse, comparing with other related areas in southeastern Brazil, despite several anthropogenic impacts to which the region is subjected. Species such as Pomacanthus arcuatus, usually common in warm waters at low latitudes, and Pinguipes brasilianus of subtropical affinity were both observed in the area. This may be explained in part by the seasonal upwelling and intrusion of the South Atlantic Central Water (SACW), with low-temperature $\left(<18{ }^{\circ} \mathrm{C}\right)$ and nutrient-rich waters close to shore (Ekau \& Knoppers, 1999). The consequent fish assemblage is a mix of tropical and subtropical elements co-occurring in the Southeastern Brazilian coast (Floeter et al., 2001). Many of these species are vagrants and very often unable to establish local populations. In fact, Joyeux et al. (2001) observed that species must be sufficiently abundant with self-recruiting populations to be considered resident in a particular location. On the other hand, vagrants are exceptionally rare and probably recruited from other sites only when conditions permit.

Floeter et al. (2001) observed that Muraenidae, Holocentridae, Serranidae, Haemulidae, Chaetodontidae, Pomacanthidae, Pomacentridae, Labridae, Scaridae, and Acanthuridae are the most distinctive reef-associated families. These families are conspicuous and relatively easy to underwater identification and, more often, they are frequently recorded amongst the 10 most speciose families in the Western and Central Atlantic (Floeter \& Gasparini, 2000).

In the Cagarras Archipelago we recorded only 49 species from the above families, despite our diving efforts over 6 months. Studies conducted in other rocky reef sites on the Brazilian coast, some in close proximity to the study area, showed much higher levels of diversity with a similar UVC method, ranging from 67 species at Baía de Ilha Grande (RJ) to 76 species at Guarapari Islands (ES) (Floeter et al., 2006).

Additionally, we observed great differences in the number of total reef fish species in Cagarras (99 spp.), comparing with the amount found in other Brazilian localities, such as, Ilha do Arvoredo, Santa Catarina (157 spp. - Hostim-Silva et al., 2006), Baía da Ilha Grande, RJ (204 spp. - Bizerril \& Costa, 2001; Ferreira et al., in press), Arraial do Cabo, RJ (91 spp. - Ferreira et al., 2001), Três Ilhas, ES (174 spp. Floeter \& Gasparini, 2000), Risca do Zumbi, PB (154 spp. - Feitoza, 2001), Tamandaré, PE (185 spp. Ferreira et al., 2001). Such differences may be due to different sampling methodologies, area covered by each survey, and sampling effort. We only recorded half of the year cycle, probably missing some species that use the area on a seasonal basis. Nevertheless, we consider the number of species found on our survey relatively high, since the area does not comprise coral reefs or highly sheltered and calm waters observed in the other areas.

The number of species in Cagarras Archipelago, mainly fishes with cryptobenthic habits, tends to increase on account of higher number of UVC and diving activities in the area, as well as different sampling methods. The role of cryptobenthic fishes in reef areas is still not well-known and usually underestimated in UVC (Rangel et al., 2005). Ackerman \& Bellwood (2000) observed 95 individuals and 36 cryptobenthic species in a $10 \mathrm{~m}^{2}$ area of a specific location. This represented approximately $50.1 \%$ of individuals and $40.4 \%$ of all reef fish species at this location (Depczynski \& Bellwood, 2003).

In this paper, we suggest that overfishing, ornamental fish harvesting, or both, are modifying local fish communities, reducing, for example, the diversity and abundance of top predators and large herbivores. According to Ferreira et al. (in press), top predators and large herbivores are the species most affected by fisheries, and the low incidence of top predators indicates severe environmental impact in reef areas, which causes unstructured trophic chains.

The trophic structure observed in Cagarras Archipelago, contrary to what was expected, showed a high density of omnivores, although the invertivores comprised a higher number of species. According to Floeter et al. (2004), invertebrate feeders, planktivores and carnivores feed on high protein and energy-rich food and are the most diverse trophic group worldwide. Low-energy resources, more available in impacted areas, could explain the great abundance of omnivores recorded.

Of the total species recorded, $35 \%$ are considered to be relevant for the Brazilian aquarium trade, and about $10 \%$ are in the top list of the most harvested reef fishes (Monteiro-Neto et al., 2003; Gasparini et al., 2005). The non-protected status of Cagarras Archipelago could be responsible for the future extinction of these species.

The Cagarras Archipelago remains an important coastal marine ecosystem, still to be more investigated. Regarding the fish assemblages, we have come with preliminary evidences that their composition feeds on both tropical and subtropical elements, but with a lesser participation of the often regarded dominant reef fish fauna. The combination of different sampling methods could provide an even higher number of species and probably new records in the study area.

Our study further supports the importance of the establishment of a marine protected area in the 
Cagarras Archipelago. The proximity of the archipelago to the city of Rio de Janeiro is an eminent threat to the ecosystem due to the multiple uses of coastal areas by the population. Pollution, uncontrolled fisheries and tourism are some of the major threats observed in the archipelago. Nevertheless, the Cagarras Archipelago provides innumerous opportunities for the development of ecotourism activities within a marine protected area. The diving industry would also benefit from this venture as more fish and natural underwater habitats are preserved and restored. Keeping that in mind, underwater photographers and recreational divers would be able to use the system in a sustainable manner. Future research should focus on underwater habitat degradation, its causes and potential ways for recovery. Also understanding more about past densities and size structure of fish communities through interviews with fishermen would provide insights about historical overfishing and the shifting baselines agenda. Establishing a marine protected area will permit a better understanding on the biological processes and on the fish community structure in the area, to support formulating policies intended to influence and determine decisions for the protection of local reef fishes.

\section{Acknowledgements}

We thank Instituto Ecomama and Tempo de Fundo Atividades Subaquáticas, for an effective cooperation that provided access to the islands. A. Aguiar, S. Marques, J. P. Mendonça-Neto, and W. Fortes, for helping in the field. L. Borges, for reviewing the English grammar. We would also like to thank two anonymous referees for important improvements to this paper. Fundação de Amparo à Pesquisa do Estado do Rio de Janeiro (FAPERJ) and Conselho Nacional de Desenvolvimento Cientıfico e Tecnológico $(\mathrm{CNPq})$, provided $\mathrm{MSc}$., $\mathrm{PhD}$ and Research Productivity fellowships for the authors. Financial support for this project has been provided by Fundação O Boticário de Proteção à Natureza (PICN 0698-2006-1). Different labs at the Marine Biology Department, Universidade Federal Fluminense, provided additional logistic and equipment support for diving operations.

\section{ReFERENCES}

Ackerman, J. L. \& Bellwood, D. R. 2000. Reef fish assemblages: a re-evaluation using enclosed rotenone stations. Mar. Ecol. Progr. Ser., 206:227-237.

Baron, R. M.; Jordan, L. K. B. \& Spielerb, R. E. 2004 Characterization of the marine fish assemblage associated with the nearshore hardbottom of Broward
County, Florida, USA. Estuar. coast. Shelf Sci., 60:431443.

Bizerril, C. R. S. F. \& Costa, P. A. 2001. Peixes Marinhos do Estado do Rio de Janeiro. Rio de Janeiro: Fundação de Estudos do Mar (FEMAR) Secretaria de Estado de Meio Ambiente e Desenvolvimento Sustentável do Estado do Rio de Janeiro.

BRASIL. Câmara dos Deputados do Brasil. 2003. Projeto de Lei No. 1.683 (autor: Deputado Federal Fernando Gabeira), aprovado em 10 de Março de 2003, instituição do Monumento Natural do Arquipélago das Cagarras, Rio de Janeiro, RJ.

Carvalho-Filho, A. 1999. Peixes da Costa Brasileira. São Paulo: Melro. 320 p.

Choat, J. H. \& Bellwood, D. R. 1991. Reef Fishes: Their History and Evolution. In:Sale, Peter F., ed. The Ecology of Coral Reef Fishes. San Diego, Cal.: Academic Press, p. 39-66.

Depczynski, M. \& Bellwood, D. R. 2003. The role of cryptobenthic reef fishes in coral reef trophodynamics. Mar. Ecol. Progr. Ser., 256:183-191.

Dutra G, F.; Allen G, R.; Werner T.; McKenna S. A. eds. 2005. A rapid marine biodiversity assessment of the Abrolhos Bank, Bahia, Brazil. RAP Bul. Biol Assem., 38. Washington, DC: Conservation International.

Ekau, W. \& Knoppers, B. 1999. An introduction to the pelagic system of the North-East and East Brazilian shelf. Arch. Fish. mar. Res., 47:113-132.

Feitoza, B. M. 2001. Composição e estrutura da comunidade de peixes recifais da Risca do Zumbi, Rio Grande do Norte. Universidade Federal da Paraíba. Dissertação de Mestrado. $156 \mathrm{p}$.

Ferreira, B. P.; Cava, F. C. \& Maida, M. 2001. Ictiofauna marinha da APA Costa dos Corais: lista de espécies através de levantamento da pesca e observações subaquáticas. Bol. Téc. Cient. CEPENE. 9(1):167180.

Ferreira, C. E. L.; Gonçalves, J. E. A. \& Coutinho, R. 2001. Community structure of fishes and habitat complexity in a tropical rocky shore. Environ. Biol. Fishes, 61:353369.

Ferreira, C. E. L.; Floeter, S. R.; Gasparini, J. L.; Joyeux, J. C. \& Ferreira, B. P. 2004. Trophic structure patterns of Brazilian reef fishes: a latitudinal comparison. J. Biogeogr., 31:1093-1106.

Ferreira, C. E. L.; Ferreira, C. G. W.; Rangel, C. A.; Mendonça-Neto, J. P.; Gerhardinger, L. C.; CarvalhoFilho, A.; Godoy, E. A.; Luiz-Júnior, O. J. \& Gasparini, J. L. In press. In: Creed, J.C. ed. RAP - Um levantamento rápido da biodiversidade marinha da Baía da Ilha Grande, Brasil. Cap. 12. Peixes Recifais.

Floeter, S. R. \& Gasparini, J. L. 2000. The southwestern Atlantic reef-fish fauna: composition and zoogeographic patterns. J. Fish Biol., 56:1099-1114.

Floeter, S. R.; Guimarães, R. Z. P.; Rocha, L. A.; Ferreira, C. E. L.; Rangel, C. A.; Nunan, G. W. \& Gasparini, J. L. 2001. Geographic variation in reef-fish assemblages along the Brazilian coast. Global Ecol. Biogeogr., 10:423-431.

Floeter, S. R.; Ferreira, C. E. L.; Dominici-Arosemena, A. \& Zalmon, I. 2004. Latitudinal gradients in Atlantic reef fish communities: a functional approach. J. Fish Biol, 64: 1680-1699. 
Floeter, S. R.; Halpern, B. S. \& Ferreira, C. E. L. 2006. Effects of fishing and protection on Brazilian reef fishes. Biol. Conserv., 128: 391-402.

Frédou, T.; Ferreira, B. P. \& Letourneur, Y. 2006. A univariate and multivariate study of reef fisheries off northeastern Brazil. ICES J. Mar. Sci., 63: 883-896.

Froese, R. \& Pauly, D. (eds). 2006. FISHBASE 02/2006. $<$ http://www.fishbase.org.>

Gasparini, J. L.; Floeter, S. R.; Ferreira, C. E. L. \& Sazima, I. 2005. Marine ornamental trade in Brazil. Biodiversity and conservation, 14: 2883-2899.

Hostim-Silva, M.; Andrade, A. B.; Machado, L. F.; Gerhardinger, L. C.; Daros, F. A.; Barreiros, J. P. \& Godoy, E. A. 2006. Peixes de costão rochoso de Santa Catarina - Ilha do Arvoredo. Itajai, SC: Editora da Universidade do Vale do Itajaí. 135p.

Joyeux, J. C. ; Floeter, S. R.; Ferreira, C. E. L. \& Gasparini, J. L.. 2001. Biogeography of tropical reef fish: the South Atlantic puzzle. J. Biogeogr., 28: 831-841.

Lodi, L. 2002. Santuário no Mar de Ipanema. Ciência Hoje, 37 (219): 60-63.

MMA, 1999. Projeto de Conservação e Utilização Sustentável da Diversidade Biológica Brasileira (PROBIO). (Biological Diversity National Program) $<$ http://www.mma.gov.br>.

MMA, 2002. Avaliação e identificação de áreas e ações prioritárias para a conservação, utilização sustentável e repartição dos benefícios da biodiversidade nos biomas brasileiros. 1. Meio ambiente. 2. Biodiversidade. 3. Política ambiental. I. Ministério do Meio Ambiente. Brasília: MMA/SBF, 2002. 404 p.

Monteiro-Neto, C.; Cunha, F. E. A.; Nottingham, M. C.; Araújo, M. E.; Rosa, I. L. \& Barros, G. M. L. 2003 Analysis of the marine ornamental fish trade at Ceará State, northeast Brazil. Biodiver. Conserv., 12:12871295.

Munro, J. L. 1996. The scope of tropical reef fisheries and their management. In: Polunin NVC, Roberts CM (eds) Reef Fisheries. London : Chapman \& Hall,. p.1-12.
Nelson, J. S. 1994. Fishes of the World. 3 ed. New York: John Wiley. 600p.

Paulay, G. 1997. Diversity and distribution of reef organisms. In: Birkeland C (ed) Life and Death of Coral Reefs. New York: Chapman \& Hall, p. 298-345.

Polunin, N. V. C. \& Roberts, C. M. (eds) 1996. Reef fisheries. London: Chapman \& Hall. 477 p.

Portal Baía de Guanabara. 1997. A Baía em dados Municípios. <http://www.portalbaiadeguanabara.org.br/ portal/municipios.asp > Accessed: Oct. 11, 2006.

Rangel, C. A.; Monteiro-Neto, C.; Ferreira, C. E. L. \& LuizJúnior, O. J. 2005. Escondidos nos recifes. Ciência Hoje, 36 (216): 66-68.

Relini, L. 2002. Occurrence of the South American fish Pinguipes brasilianus (Pinguipedidae) in the Mediterranean. Cybium, 26(2): 147-149.

Roberts, C. M. \& Hawkins, J. P. 2000. Fully-protected marine reserves: a guide. Washington, DC : WWF Endangered Seas Campaign. <.(http://www.panda.org/ endangeredseas/) $>$.

Sale, P. F. 1991. Reef fish communities: open non-equilibrial systems. In: P.F. Sale (ed.).The Ecology of fishes on coral reefs. San Diego, Cal.: Academic Press, p. 564598.

Secchin, C. 2002. Mar do Rio - Fronteira azul da cidade. Rio de Janeiro: Andrea Jakobsson Estúdio. 208 p.

Spalding, M. D.; Ravilious, C. \& Green, E. P. 2001. World Atlas of coral reefs. University of California Press. 424 p.

Valentin, J. L.; Tenenbaum, D. R.; Bonecker, A.; Bonecker, S. L. C.; Nogueira, C. R.; Paranhos, R. \& Villac, M. C. 1999. Caractéristiques hydrologiques de la baie de Guanabara (Rio de Janeiro, Brésil). J. Rech. Océanogr., 24(1): 33-41.

(Manuscript received 06 June 2006; revised 13 September 2006; accepted 18 October 2006) 